\title{
MENUMBUHKEMBANGKAN BUDAYA ORGANISASI DI SMPIT NUR HIDAYAH SURAKARTA
}

\author{
Moh. Pandoyo, Eko Supriyanto, dan Djalal Fuadi \\ SMP Islam Al Azhar 21 Sukoharjo \\ Program Studi Administrasi Pendidikan Sekolah Pascasarjana \\ Universitas Muhamadiyah Surakarta \\ mohpandoyo@yahoo.com
}

\begin{abstract}
This research learns about the role of the principal in developing organization culture, with case study in SMPIT Nur Hidayah Surakarta. The problem is focus on the role of principal in socializing, maintining and developing organization culture for the teachers and employes of SMPIT Nur Hidayah. This study aims to describe the role of principal in developing organization culture for the teachers ang employes of SMPIT Nur Hidayah. This study uses qualitative research conducted in SMPIT Nur Hidayah Surakarta. The main subjects in this study were principals, teachers and employes. Data collection techniques used in this study is interview, observation, and contain analysis. The validity of the data in research by data triangulation. Data analysis techniques in this study using an interractive analysis model of Miles and Huberman through data collection, data reduction, data presentation and conclusion. The results of this study show that: (1) socialization of the organizational culture for the teachers and employes are the effort to spread informations about organizational culture and increase organizational culture concept, (2) maintenance of organizational culture for the teachers and employes preserve the existent organization culture so it will last longer and stronger in the hearts of the teachers and employes and give them identity in the organization (3) the development of organizational culture is done by developing sincerity culture, knowledge culture, and moslem life behaviour culture that direct to amar ma'ruf nahi munkar.
\end{abstract}

Keywords: organizational culture, socialization, maintenance, development

Abstrak. Penelitianinimengkaji peranankepala sekolah dalammenumbuhkembangkan budaya organisasi, dengan studi kasus di SMPIT Nur Hidayah Surakarta. Permasalahan yang diteliti difokuskan pada bagaimana peran kepala sekolah dalam mensosialisasikan, memelihara dan mengembangkan budaya organisasi bagi guru dan karyawan di SMPITNur Hidayah. Tujuan dari penelitian adalah untuk mendeskripsikan peran kepala sekolah dalam menumbuhkembangkan budaya organiasi bagi guru dan karyawan di SMPIT Nur Hidayah. Penelitian ini menggunakan metode penelitian kualitatif yang dilakukan di SMPIT Nur Hidayah Surakarta. Subyek utama dalam penelitian ini adalah kepala sekolah, guru dan karyawan. Teknik pengumpulan data yang dipergunakan dalam penelitian ini adalah wawancara, observasi dan analisis dokumen. Keabsahan data dalam penelitian dengan triangulasi data. Teknik analisis data dalam penelitian ini menggunakan interractive analysis model Miles dan Huberman yaitu pengumpulan data, reduksi data dan penyajian data serta kesimpulan. Hasil dari penelitian ini adalah: (1) Sosialisasi budaya organisasi bagi guru dan karyawan diarahkan kepada upaya memperluas informasi dan pemahaman guru dan karyawan tentang budaya organisasi (2) Pemeliharaan budaya organisasi 
bagi guru dan karyawan dilakukan untuk melestarikan budaya organisasi yang telah ada tertanam semakin kokoh dalam diri guru dan karyawan dalam proses perjalanan organisasi sehingga memberikan ciri khusus organisasi (3) Pengembangan budaya organisasi dilakukan melalui peningkatan kualitas dan kuantitas pelaksaan budaya semangat, kebersamaan, keilmuan dan nilai perilaku hidup muslim amar ma'ruf nahi munkar menuju akhlaqul karimah.

Kata kunci: budaya organisasi, sosialisasi, pemeliharaan, pengembangan

\section{Pendahuluan}

Pendidikan dalam Undang - Undang Nomor 20 Tahun 2003 tentang sistem pendidikan nasional pasal 1 didefinisikan usaha sadar dan terencana untuk mewujudkan suasana belajar dan proses pembelajaran agar peserta didik secara aktif mengembangkan potensi dirinya untuk memiliki kekuatan spiritual keagamaan, kepribadian, pengendalian diri, akhlak mulia kecerdasan, serta keterampilan yang diperlukan dirinya, masyarakat, bangsa dan negara. Pendidikan tidak dapat dilaksanakan jika tidak dikelola oleh suatu organisasi, seperti organisasi satuan pendidikan, organisasi pemerintah, dan lainnyayangberkaitandenganpenyelenggaran pendidikan (Sagala, 2013:13). Berdasarkan kedudukan organisasi, maka pendidikan dapat dikelola oleh suatu organisasi yang berbentuk institusi pendidikan mulai dari tingkat pemerintah pusat, pemerintah daerah, dan satuan pendidikan. Kurangnya pendekatan budaya oleh organisasi pendidikan dianggap menjadi penyebab kurang optimalnya hasil dari upaya peningkatan kualitas pendidikan. Koentjaraningrat (2003:72) mendefinisikan kebudayaan sebagai keseluruhan sistem gagasan, tindakan dan hasil karya manusia dalam rangka kehidupan masyarakat yang dijadikan milik diri manusia dengan cara belajar. Dalam lingkungan internal organisasi selalu berkembang budaya organisasi (Wirawan, 2007:5). Budaya organisasi dimiliki organisasi yang terbentuk dari sifat khas organisasi sebagai subjek dan objeknya. Schein, seorang pakar budaya organisasi (1995) mendefinisikan bahwa budaya organisasi sebagai pola asumsi dasar yang ditemukan atau dikembangkan oleh suatu kelompok orang selagi mereka belajar untuk menyelesaikan problem - problem, menyesuaikan diri dengan lingkungan eksternal, dan berintegrasi dengan lingkungan internal. Budaya organisasi menurut Hoy dan Miskel (2014:270) adalah sebuah sistem orientasi bersama yang mempersatukan unitnya dan memberinya identitas khusus. Menurut Schwartz dan Davis, budaya organisasi merupakan harapan dan pola kepercayaan yang dianut oleh anggota organisasi. Sedang menurut Ndraha (2003:53), budaya organisasi dapat dilihat sebagai fenomena sosial dari level makro dan bisa juga sebagai fenomena administratif dari sudut mikro, dan organisasi adalah masukan bagi usaha mencapai tujuan. Jadi, budaya organisasi merupakan karakteristik organisasi, bukan individu anggotanya.

Manajemen sekolah yang tidak mengindahkan nilai budaya akan menyebabkan institusi pendidikan sebagai entitas yang terlepas dari masyarakatnya, sedang stoke holder sekolah adalah juga anggota masyarakat, dan alumni institusi pendidikan akan kembali ke masyarakat. Kepala sekolah sebagai leader, tidak hanya membuat perencanaan, proses organisasi, pelaksanaan dan monitoring menggunakan analisis SWOT, kepala sekolah mempunyai peranan sebagai penggerak dinamika sekolah yang dipimpinannya (Tahalele, 2006:11). Mulyasa (2004:158) juga mengemukakan bahwa kepala sekolah juga merupakan pengendali dan penentu arah yang hendak dicapai sekolah. Perhatian kepala sekolah yang kurangnya atau bahkan tidak mendapatkan perhatian terhadap budaya organisasi ini dalam waktu lama panjang 
dikhawatirkan berakibat tidak begitu bagus terhadap tercapainya program pemerintah dalam bidang pendidikan, yang salah satunya adalah peningkatan kualitas pendidikan. Perhatian peneliti mengadakan penelitian tentang budaya organisasi berangkat dari keprihatinan pada kenyataan pada tersebut diatas.

Berkaitan dengan persoalan pokok yang dikaji dalam penelitian ini adalah berkaitan dengan peran kepala sekolah dalam budaya organisasi, maka masalah yang dikaji tersebut dapat dirumuskan sebagai berikut : (1) Bagaimana peranan kepala SMPIT Nur Hidayah dalam implementasi budaya organisasi kepada guru dan karyawan ? (2) Bagaimana peranan kepala SMPIT Nur Hidayah dalam memelihara budaya organisasi bagi guru dan karyawan? (3) Bagaimana peranan kepala SMPIT Nur Hidayah dalam menumbuhkembangkan budaya organisasi bagi guru dan karyawan ? Tujuan diadakan penyelidikan terhadap peranan kepala SMPIT Nur Hidayah Surakarta dalam mengembangkan budaya organisasi bagi guru dan karyawan yang ada adalah : (1) Mendeskripsikan peran kepala SMPIT Nur Hidayah dalam implementasi budaya organisasi kepada guru dan karyawan, (2) Mendeskripsikan peran kepala SMPIT Nur Hidayah dalam memelihara budaya organisasi bagi guru dan karyawan yang ada, (3) Mendeskripsikan peran kepala SMPIT Nur Hidayah dalam menumbuhkembangkan budaya organisasi agar menjadi referensi bagi guru dan karyawan dalam melakukan tugas bekerja dan meningkatkan kinerja guru dan karyawan SMPIT Nur Hidayah Surakarta.

\section{METODE PENELITIAN}

Penelitian mempunyai jenis berupa studi kasus, sebagai penyelidikan yang berfokus dengan suatu tingkatan lebih rinci dari SMPIT Nur Hidayah Surakarta sebagaimana dikemukakan Maxfield dalam Nasir (2003:57). Penelitian desain studi kasus dibagi menjadi dua jenis studi kasus sebagaimana dinyatakan Muhajir, yaitu prospektif dan retrospektif. Penelitian ini menggunakan prospektif, bukan retrospektif dengan argumen: (1) menempatkan perkembangan objek dengan cara tidak ada kelainan, (2) penelitian diharapkan mempunyai hasil simpulan yang bisa dipakai sebagai proses memikir perkembangan ke arah esok hari. Tempat yang diteliti berlokasi di Sekolah Menengah Pertama Islam Terpadu Nur Hidayah Surakarta yang beralamat di Jalan Kahuripan Utara, Sumber, Kecamatan Banjarsari, Kotamadya Surakarta kode pos 57138. Pemilihan lokasi penelitian di SMPIT Nur Hidayah Surakarta, karena kekhasan SMPIT Nur Hidayah dalam budaya organisasi yang dimilikinya. Ciri khas yang dimaksud antara lain: (1) jiwa semangat guru dan karyawan, (2) kebersamaan guru dan karyawan yang sangat kompak, (3) minat guru dan karyawan dalam menuntut ilmu termasuk tinggi sebagai manifestasi dari dilaksanakannya budaya keilmuan dan (4) penerapan perilaku hidup muslim yang kuta, khususnya amar ma'ruf nahi munkar.

Penelitian dengan pendekatan kualitatif sebagaimana dikemukakan oleh W Creswl (Patilima, 2005:65-67), disebabkan (1) mempunyai keadaan sebenarnya, perlakuan istimewa tidak diberikan kepada SMPIT Nur Hidayah, dipakai sumber data langsung (2) Mempunyai sifat deskriptif, yang berarti perolehan data dijelaskan dalam bentuk katakata, (3) data dianalisis dengan cara induktif, dengan maksud bahwa diawali dengan realita yang didapat dari lokasi penelitian, secara etik dan emik peneliti melakukan analisis agar didapatkan arti yang diinginkan. Moleong (2002:3) menyatakan bahwa pendekatan kualitatif digunakan mengingat penelitian yang dilaksanakan menghasilkan penjelasan dari orang dan perilaku yang dilihat. Sumber data yang hendak digunakan memperoleh data untuk menjelaskan, melakukan analisis dalam kaitan penulisan tesis ini diperoleh dari : (1) Narasumber dari Kepala SMPIT Nur Hidayah Surakarta， Guru dan karyawan SMPIT Nur Hidaya, Pengurus Yayasan Nur Hidayah Surakarta, Wali Siswa, Dokumen, (2) Peristiwa dan tempa (3) Dokumen 
Yayasan dan sekolah. Pengumpulan Data menggunakan Wawancara mendalam (indepth interview), pengamatan, Analisis dokumen (content analysis). Model analisis yang dipakai adalah model interractive analysis model sebagaimana yang dikemukakan Miles dan Huberman. Miles dan Huberman (2002:16) mengungkapkan analisis data kualitatif meliputi tiga macam kegiatan yaitu pengurangan data, penyajian data dan penarikan kesimpulan

\section{Hasil Penelitian Dan Pembahasan Hasil Penelitian}

\section{A. Deskripsi dan Analisis Data Penelitian}

Aktivitas sosialisasi budaya organisasi dilakukan pada awal pelajaran dan awal tahun melalui kegiatan workshop dan rapat kerja sekolah. Workshop dilaksanakan diluar sekolah dengan mengundang narasumber dari ahli pendidikan. Rapat kerja juga meneguhkan visi sekolah yang menjadi cita cita sekolah dan misi yang dijalankan sekolah. visi SMPIT Nur Hidayah adalah terwujudnya sekolah yang efektif dan bermutu dalam mewujudkan generasi cerdas, kreatif, mandiri, dan berakhlak mulia. Budaya organisasi yang disosialisasikan kepada guru dan karyawan yaitu budaya dasar organisasi (semangat, ukhuwah, ilmu, amar ma'ruf nahi munkar), perubahan struktur, standar pengelolaan, displin guru, evaluasi program kerja. Budaya ikhlas, budaya ukhuwah, budaya keilmuan, budaya amar ma'ruf nahi munkar, budaya disiplin, budaya tidak merokok dan budaya menutup aurat juga menjadi titik tekan yayasan. Proses sosialisasi budaya organisasi dilaksanakan pada awal semester dan awal tahun. Setiap 6 bulan ada pertemuan dengan guru dan karyawan. Kemudian setiap bulan ada rapat kerja setiap tanggal 1 . Sosialisasi juga dilaksanakan pada pembinaan rutin kepala sekolah. Sosialisasi juga dapat terlihat dari perilaku keseharian kepala sekolah, contohnya dalam budaya semangat

Program - program sekolah dilaksanakan dalam rangka menjaga dan memelihara budaya organisasi yang baik, diantaranya supervisi kepala sekolah. Kepala sekolah menumbuhkan semangat bekerja dengan memberikan reward berupa umroh dan menghindarkan punishment. Diketahui program kebersamaan di SMPIT Nur Hidayah seperti kegiatan mabit (menginap) bersama di sekolah dan yayasan, forum diskusi bersama guru putri, kegiatan sosial bersama seperti menjenguk orang sakit, mendatangi resepsi pernikahan, menjenguk bayi yang baru lahir. Budaya keilmuan dapat dilakukan dengan kegemaran membaca, mengikuti kegiatan ilmiah pengembangan keprofesian guru dan karyawan, atau bahkan mengikuti studi lanjut S1 ataupun S2 dan S3. Sedangkan budaya amar ma'ruf nahi munkar ditujukan agar dapat memberikan nasihat rekan lain dalam meninggikan hasil kerja optimal, atau mengingatkan rekan yang melakukan kekhilafan, dengan seperti itu akan terjadi langkah yang sama.

Budaya organisasi SMPIT Nur Hidayah selalu dikembangkan untuk meningkatkan kinerja guru dan karyawan sekaligus meningkatkan kepercayaan masyarakat terhadap pendidikan di SMPIT Nur Hidayah. Diantara penumbuhkembangan yang dilakukan kepala sekolah adalah penjagaan terhadap ciri khas SMPIT Nur Hidayah, meningkatkan kualitas lulusan siswa dan kualitas guru karyawan, peningkatan kualitas keagamaan guru karyawan, peningkatan budaya amar ma'ruf nahi munkar.

\section{B. Temuan}

Penelitian yang dilakukan di SMPIT Nur Hidayah Surakarta, peneliti mendapatkan beberapa temuan yang berkaitan dengan penumbuhkembangan budaya organisasi baik hasil penggalian data dari wawancara mendalam, observasi maupun studi dokumen. Temuan - temuan tersebut antara lain: (1) Peranan Kepala SMPIT Nur Hidayah dalam Implementasi Budaya Organisasi. Budaya organisasi yang diimplementasikan Yayasan Nur Hidayah maupun SMPIT Nur Hidayah kepada guru dan karyawan adalah budaya semangat, kebersamaan, keilmuan, 
amar ma'ruf nahi munkar, disiplin, tidak merokok dan menutup aurat. Kepala SMPIT Nur Hidayah sudah mengimplementasikan budaya organisasi kepada guru dan karyawan melalui (a) rapat kerja sekolah di awal tahun pelajaran dan awal tahun baru, (b) pembinaan - pembinaan rutin tiap bulan dan (c) terlihat dari perilaku keseharian kepala sekolah, (2) Peranan Kepala SMPIT Nur Hidayah dalam Memelihara Budaya Organisasi. Pemeliharaan budaya organisasi melalui supervisi kepala sekolah dan monitoring kegiatan oleh kepala SMPIT Nur Hidayah kepada guru dan karyawan. Budaya organisasi yang perlu dan selalu di pelihara oleh kepala sekolah adalah budaya semangat, kebersamaan, keilmuan dan budaya amar ma'ruf nahi munkar, (3) Peranan Kepala Sekolah dalam Menumbuhkembangkan Budaya Organisasi. Menjaga ciri khas SMPIT Nur Hidayah yaitu budaya akhlaq (yang didalamnya budaya semangat, kebersamaan, keilmuan dan amar ma'ruf nahi munkar), budaya al qur'an dengan membaca dan menghafalnya, budaya berpenampilan islami, budaya guru itu ustadz, budaya menutup aurat dan tidak merokok. Mengembangkan sarana atau kegiatan yang bisa menunjukkan kemampuan/ kualitas siswa dan kualitas guru. Menumbuhkembangkan budaya khas guru dan karyawan berupa pengajian yayasan untuk menambah wawasan keislaman dan menjaga keruhanian guru dan karyawan. Penumbuhkembangan budaya guru dan karyawan, terutama penekanan budaya mengajak kepada kebaikan dan mencegah kemungkaran

\section{Pembahasan}

Budaya organisasi yang terdapat di SMPIT Nur Hidayah Surakarta secara garis besar bisa diperhatikan pada visinya yang direpresentasikan dalam kalimat singkat efektif, bermutu dan berakhlak mulia. Yayasan Nur Hidayah berusaha untuk melakukan penyelenggaraan pendidikan dengan ciri tertentu, hal tersebut bisa diamati pada kurikulum dan pola pembelajaran yang ditentukan oleh SMPIT Nur Hidayah. Kurikulum yang ditetapkan adalah perpaduan antara kurikulum yang ditentukan Kementrian Pendidikan dan Kebudayaan dan kurikulum JSIT yang ditetapkan oleh Jaringan Sekolah Islam Terpadu.

\section{Peranan Kepala Sekolah dalam Implementasi Budaya Organisasi}

Kegiatan baik yang tidak disosialisasikan dengan baik maka hasilnya tidak menjadi maksimal. Menurut Broom bahwa sosialisasi merupakan proses seorang pribadi mengembangkan diri melalui hubungan dengan orang lain sehingga mendapatkan pengetahuan tentang nilai - nilai yang berlaku pada komunitas tempat tinggalnya sehingga seseorang memperoleh identitas dan mengembangkan keinginannya Rohidi (1994:12). Budaya organisasi sebagaimana yang diinginkan peletak dasar, petinggi yayasan atau prinsip organisasi tidak akan diketahui oleh anggota organisasi tanpa adanya sosialisasi. Sependapat penelitian Jurman (2014) bahwa kurangnya sosialisasi peratutan sekolah menjadi salah satu faktor penghambat kinerja guru.

Kepemimpinan pimpinan satuan pendidikan dalam mensosialisasikan budaya organiasi ditujukan bagaimana peran pimpinan sekolah sehingga guru dan karyawan mengetahui dan paham budaya organisasi. Sebagaimana dinyatakan Zanden bahwa sosialisasi sebagai interaksi agar memahami dan memberikan peluang kepada individu untuk mengenal cara berpikir, berperanan dan berkelakuan sesuai dengan nilai - nilai yang berlaku (Rohidi, 1994:13). Budaya - budaya dasar dalam budaya organisasi di Nur Hidayah sangat dipengaruhi nilai - nilai islam. Budaya - budaya dasar yang dimaksud adalah : (1) budaya semangat, (2) budaya kebersamaan, (3) budaya keilmuan, (4) budaya hidup muslim amar ma'ruf nahi munkar. Serangkaian interviu mendalam dengan pimpinan satuan pendidikan, guru, dan karyawan, budaya - budaya dasar dalam melakukan pekerjaan diantaranya dapat 
dijelaskan sebagai berikut : (1) budaya semangat bisa dijelaskan diantaranya pada aktivitas keseharian guru dan karyawan berupa : berangkat bekerja ke tempat bekerja tidak terlambat, melakukan persiapan dengan tepat, selalu berada di tempat kerja sesuai ketentuan peraturan kepegawaian yang ditentukan, pantang menyerah dalam menyelesaikan persoalan, mengajar tepat pada waktu, pulang sesuai ketentuan, pendampingan anak walaupun diluar jam KBM, (2) budaya kebersamaan, diantaranya bisa dijelaskan dalam aktivitas keseharian berupa kegiatan makan siang bersama, menengok teman yang sakit, menghadiri pernikahan teman, berkunjung kepada pasangan yang melahirkan, bersama - sama mengikuti pengajian pembinaan Yayasan Nur Hidayah, melakukan rapat - rapat dalam membuat administrasi pembelajaran, melaksanakan aktivitas silaturahmi bulan syawal, mengikuti aktivitas kekeluargaan seperti family gathering keluarga besar SMPIT Nur Hidayah dan rekreasi bersama, mengadakan olahraga bersama, bekerja dalam kepanitiaan, (3) budaya keilmuan, diantaranya dijelaskan dan diaplikasikan lewat aktivitas: program tahsin qur'an pekanan, kegiatan Musyawarah Guru Mata pelajaran (MGMP) Surakarta, diskusi dan musyawarah dalam menyusun perangkat pembelajaran, melaksanakan aktivitas melanjutkan belajar ke strata lebih tinggi, kesukaan membaca buku di perpustakaan, budaya literasi di sekolah, pembinaan dan pengembangan keprofesian guru dan karyawan, (4) budaya hidup muslim amar ma'ruf nahi munkar, antara lain dijabarkan dalam kegiatan mengingatkan teman lain yang tidak sesuai dengan norma agama atau aturan yayasan (seperti merokok, berduaan dengan lawan jenis/ khalwat, tidak menutup aurat) dalam tausiyah pekanan bergilir, mengajak shalat sunnah maupun sholat wajib berjamaah, mabit bersama, mengikuti pengajian rutin pekanan dan bulanan, membuat tulisan tentang tentang ajakan kebaikan dan mencegah kemungkaran di lingkungan sekolah, menolong teman sejawat yang membutuhkan pertolongan, pertemuan orang tua siswa, tadarus keliling, tahajud call.

Sosialisasi budaya organisasi di SMPIT Nur Hidayah dilaksanakan dengan macam macam cara, diantaranya lewat musyawarah/ rapat, selebaran, situs web sekolah, pembinaan rutin dan pembinaan sewaktu waktu yang dilaksanakan pimpinan sekolah. Sosialisasi budaya organisasi bukan hanya dapat dilaksanakan kepala satuan pendidikan, tetapi juga bisa dilaksanakan oleh petinggi Yayasan Nur Hidayah

\section{E. Peranan Kepala Sekolah dalam Memelihara Budaya Organisasi}

Dalam rangka menggapai tujuan tersebut, SMPIT Nur Hidayah sudah berusaha melaksanakan berbagai usaha sebagaimana teori yang dinyatakan oleh Sondang P Siagian (1995:233) yang diantaranya mengemukakan bahwa budaya organisasi mementingkan "institusionalisasi" yang bermakna harus ada usaha sebenarnya untuk mempertahankan kelestarian budaya organisasi yang ada, lewat penentuan peraturan - peraturan tertentu. Usaha "institusionalisasi" budaya organisasi bagi guru dan karyawan di SMPIT Nur Hidayah dilaksanakan melewati berbagai macam usaha, diantaranya: (a) Penetapan peraturan kepegawaian Yayasan Nur Hidayah yang harus ditandatangani oleh setiap pegawai baik guru maupun karyawan, (b) pembinaan rutin oleh Yayasan Nur Hidayah, (c) pembinaan rutin kepala sekolah, (d) pembinaan rutin pekanan dari pembina yang ditunjuk dari Yayasan Nur Hidayah. Pemeliharaan budaya organisasi di SMPIT Nur Hidayah sangat kuat kaitannya dengan keefektifan organisasi Nur Hidayah seperti teori yang dinyatakan oleh Sondang P Siagian (1995), yaitu untuk : (a) menumbuhsuburkan semangat kebersamaan guru dan karyawan, (b) meningkatkan rasa memiliki organisasi (sense belonging). Beberapa langkah pemeliharaan budaya organisasi di SMPIT Nur Hidayah diantaranya adalah; (1) Supervisi Kepala Sekolah. hakikat supervisi akademik 
adalah serangkaian kegiatan membantu guru mengembangkan kemampuannya mengelola proses pembelajaran untuk mencapai tujuan pembelajaran. Esensi supervisi akademik sama sekali bukan menilai unjuk kerja guru dalam mengelola proses pembelajaran, melainkan membantu guru mengembangkan kemampuan profesionalisme guru dalam pelaksanaan tugasnya. Jadwal supervisi dilaksanakan satu kali dalam enam bulan. (2) Pengawasan Kegiatan. Pengawasan aktivitas dilakukan kepada guru dan karyawan setiap waktu, pengawasan bisa dirancang dengan tulisan maupun tidak tertulis. Lewat aktivitas pengawasan, pimpinan sekolah bisa mendapatkan informasi secara langsung aktivitas belajar mengajar dan tugas lain yang dilaksanakan guru dan karyawan.

Adapun budaya dasar dalam melakukan pekerjaan yang diperlukan dipelihara sebagai asas dalam bekerja bagi guru dan karyawan adalah : (1) Pemeliharaan budaya semangat. Usaha yang dilaksanakan pimpinan SMPIT Nur Hidayah dalam memelihara budaya organisasi, menurut observasi dan rangkaian interviu diantaranya dengan pembinaan non reguler dan pembinaan reguler. Pembinaan non reguler/ tidak rutin merupakan usaha pembinaan yang dilaksanakan pimpinan sekolah pada waktu diperlukan. Pembinaan reguler adalah pembinaan yang dilaksanakan kepala satuan pendidikan kepada guru dan karyawan walaupun tidak ada insiden yang dilihat perlu dilanjutkan penyikapannya. Berdasarkan pengamatan dan wawancara yang dilakukan, dapat didentifikasi perwujudan budaya semangat yang ditekankan dan dilestarikan dan dilaksanakan oleh guru dan karyawan diantaranya adalah; Berangkat ke sekolah tidak terlambat, Pulang dari sekolah juga tepat waktu, bahkan melebihi waktu, Lengkapnya persiapan mengajar, Penataan tempat belajar sesudah usai pembelajaran, Kegiatan belajar mengajar berjalan tertib, Guru - guru menyambut siswa dipagi hari, Guru - guru melaksanakan kegiatan diluar jam kegiatan belajar mengajar seperti tadarus keliling ke rumah siswa, Frekuensi ijin ketidakhadiran guru dan karyawan sangat rendah, guru yang tidak hadir kurang dari 2\%. (2) Pemeliharaan budaya kebersamaan. Suatu institusi pendidikan memerlukan hal bersama dari guru dan karyawannya dalam melaksanakan aktivitasnya, seperti yang dinyatakan oleh Sergiovani (1986) bahwa pada sebuah organisasi perlu dibangun kebersamaan dan keteraturan oleh pemimpinnya. Kebersamaan ini memperlihatkan hubungan soaial yang kuat. Menurut penelitian Balkar (2015) bahwa hubungan sosial yang kuat merupakan salah satu karakteristik budaya sekolah yang diberdayakan (Empowering School Culture). Berdasarkan observasi dan serangkaian wawancara, dapat diidentifikasi nilai kebersamaan guru dan karyawan diantaranya adalah terlihat pada : Serentak mengunjungi kalo ada guru atau karyawan mendapatkan kesedihan atau mendapat kegembiraan, Serentak dalam pengajian reguler pekanan dalam halaqoh dan pengajian yayasan, Adanya family gathering setahun sekali dan rekreasi keluarga untuk mempererat kekeluargaan di SMPIT Nur Hidayah, Membuat perangkat pembelajaran, Adanya kegiatan halal bihalal setahun sekali, Mengikuti kegiatan mabit bersama di yayasan, Rutin melaksanakan makan siang bersama, Melaksanakan olahraga bersama guru dan karyawan, Bersama - sama membimbing siswa dalam lomba , Bersamasama dalam kepanitiaan dalam melaksanakan kegiatan (3) Pemeliharaan budaya keilmuan. Budaya keilmuan para guru bukan saja sekedar pada wilayah pengetahuan faktual yang mengemukakan urgennya penambahan kapasitas keilmuan atau belajar sepanjang hayat, tetapi secara empirik terlihat adanya sejumlah 15 orang guru atau karyawan yang studi lanjut. Peranan kepala sekolah dalam memelihara budaya keilmuan bisa tampak pada menekankan dalam pertemuan - pertemuan, atau kesempatan tidak formal. Ada beberapa aktivitas yang memperoleh penekanan kepala satuan pendidikan dalam pelaksanaanya, aktivitas itu diantaranya adalah: Forum diskusi yang 
dilaksanakan dalam pembuatan perangkat belajar mengajar, Pengajian rutin tiap sabtu dalam rangka meningkatkan pemahaman keilmuan agama islam, Program tahsin al qur'an, Guru mengikuti kegiatan MGMP Mata Pelajaran Tingkat Kota Surakarta, Guru mengikuti pengembangan keprofesian guru yang dilaksanakan oleh JSIT maupun kedinasan, Karyawan mengikuti workshop yang dilaksanakan kedinasan maupun JSIT, Guru dan karyawan melanjutkan studi ke jenjang yang lebih tinggi. (4) Pemeliharaan budaya perilaku hidup muslim berupa amar ma'ruf nahi munkar. Yayasan Nur Hidayah menitikberatkan perilaku hidup muslim amar ma'ruf nahi munkar kepada pegawainya khususnya guru dan karyawan di SMPIT Nur Hidayah lewat berbagai cara. Membangun budaya islami di sekolah adalah merupakan tugas dan tanggung jawab kepala sekolah dan seluruh stake holder pendidikan khususnya lembaga pendidikan islam (Mala, 2015).

Berhubungan dengan usaha memelihara budaya organisasi, Bogdan (1988:29) memberitahukan masukan agar pimpinan sekolah, sebagai pemimpin pendidikan memiliki kemampuan untuk : (a) membangkitkan dan memupuk percaya diri para guru dan karyawan, (b) membina dan memupuk kerjasama dalam mengajukan melaksanakan program supervisi, (c) mendorong dan membimbing guru serta segenap staf sekolah agar mereka dengan penuh kerelaan dan tanggung jawab berpartisipasi secara aktif pada setiap usaha sekolah untuk mencapai tujuan yang yang telah ditetapkan. Selznik menyatakan bahwa seorang pemimpin mempunyai fungsi, antara lain: mempertahankan keutuhan organisasi, yang berarti pemimpin mewakili organisasi pada umum dan kepada stafnya seperti halnya pemimpin mencoba untuk mengajak pada bawahan mengikuti keputusannya agar fungsi tersebut dapat dilaksanakan (Wahjosumidjo, 2001:42). Berdasarkan observasi dan rangkaian wawancara kepada guru SMPIT Nur Hidayah terlihat bahwa usaha memegang teguh utuhnya organisasi bukan saja sekedar dilaksanakan dengan memakai pelindung dibalik peraturan yang ditentukan Yayasan. Aktivitas diluar waktu bekerja ternyata lebih tepat untuk diperuntukan untuk utuhnya organisasi. Ceramah keagamaan guru dan karyawan SMP, rapat - rapat guru - guru dengan walisiswa, supervisi, arahan pimpinan SMP, merupakan upaya efektif untuk utuhnya organisasi. Menurut penelitian Paulus Mikku Ate (2014) penentuan pemimpin sekolah oleh yayasan pengelola lembaga merupakan upaya yang dilakukan untuk melanggengkan budaya organisasi sekolah.

\section{F. Peranan Kepala Sekolah dalam Menumbuhkembangkan Budaya Organisasi}

Pengembangan budaya organisasi seharusnya dilaksanakan, seperti dinyatakan oleh Syafarudin (2002:99) bahwa perubahan budaya sekolah pada intinya ditentukan oleh budaya yang dikembangkan oleh kepala sekolah bersama dengan guru dan karyawan. Kepala sekolah memainkan peran yang penting dalam rangka peningkatan prestasi sekolah baik akademis maupun non akademis (Suranto, 2005). Peran kepala sekolah juga sangat strategis dalam rangka mengembangkan budaya sekolah baik staf maupun siswanya (Amir, 2011). Pengembangan budaya organisasi dimanfaatkan dalam rangka meningkatnya kinerja dan meningkatnya harapan orang banyak. Ini dikuatkan dengan penelitian Arifin (2014) bahwa budaya organisasi positif dan signifikan terhadap kinerja guru. Zubaidah dan Ayuningtyas (2015) juga menambahkan budaya organisasi di sekolah mempengaruhi peningkatan motivasi, prestasi belajar siswa, kepuasan kerja dan profesionalisme guru. Berdasarkan observasi dan interviu yang dilaksanakan bisa dinyatakan bahwa penumbuhkembangan nilai hidup muslim amar ma'ruf nahi munkar yang dilaksanakan kepala SMPIT Nur Hidayah, ditujukan kepada : Pertama, selalu memelihara ciri khusus SMP Islam Terpadu, lewat aplikasi pengembangan kurikulum yang dibuat oleh 
tim pengembang kurikulum, selain kurikulum nasional yang ditentukan Kementrian Pendidikan dan Kebudayaan. Ciri khusus islam ini bukan saja berpengaruh pada materi yang disampaikan kepada peserta didik, tetapi juga tindakan yang harus dilaksanakan guru untuk memberitahukan integrasi iman dan taqwa serta nasihat - nasihat kebaikan (amar ma'ruf). Kedua, menyelenggarakan aktivitas yang diperuntukkan sebagai ajang menunjukkan kemampuan dalam banyak macam aktivitas, contohnya berbagai perlombaan dalam rangka Hardiknas (Hari Pendidikan Nasional) atau Hari Guru Nasional (HGN) atau peringatan hari besar islam. Ketiga, sangat menitikberatkan kepada para guru dan karyawan untuk datang pada acara ceramah keagamaan yang dibuat oleh yayasan dan sekolah, hal ini mempunyai maksud agar guru dan karyawan memperoleh ketenangan jiwa menuju semangat, keikhlasan, keilmuan dan perilaku hidup muslim. Keempat, antara guru dan karyawan, perlu saling menguatkan dan menasihati untuk mengarahkan kepada perbuatan baik dan menasihati kawan jika melaksanakan tindakan yang tidak mengindahkan peraturan kepegawaian dan peraturan organisasi.

Pengembangan budaya kepada anggota organisasi juga dilaksanakan sebagiamana yang dikemukakan Kotter (1990:45) melalui (a) Menyelaraskan manusia melalui kegiatan mengkomunikasikan arahan bagi kerjasama di seluruh tingkatan organisasi, sehingga mempengaruhi tim untuk memahami visi dan strategi., (b) Memotivasi dan menginspirasi staf melalui peningkatan sumber daya manusia melalui studi lanjut bagi guru yang belum memenuhi ketentuan perundangan yang berlaku, (c) Menghasilkan perubahan, baik berupa produk baru sebagaimana yang diinginkan masyarakat, lewat pengembangan berbagai sarana prasarana dan mengikut sertakan peserta didik berbagai perlombaan sehingga sangat mungkin SMPIT Nur Hidayah semakin mempunyai jiwa kompetisi di wilayah Surakarta, Provinsi Jawa Tengah, level nasional dan level internasional.
Dalam rangka menggapai tujuan tersebut beberapa hal dapat yang bisa dilihat sebagai usaha kepala satuan pendidikan mengembangkan budaya organisasi bagi guru dan karyawan yang dilaksanakan untuk tujuan seperti dinyatakan Sondang P Siagian (1995:235) yang berupa pemberdayaan individu dan pengakuan kinerja. Tujuan pengembangan budaya organisasi yang dilaksanakan oleh kepala SMPIT Nur Hidayah, ditujukan kepada peningkatan kualitas dan kuantitas. Peningkatan jumlah dengan maksud bahwa unsur budaya organisasi yang akan dikerjakan oleh sebagian guru dan karyawan, ditingkatkan agar bisa dikerjakan seluruh guru dan karyawan. Pada sisi yang berbeda, peningkatan jumlah juga bisa diberitahukan aktivitas baru yang dianggap akan menjadi bagian budaya organisasi. Sementara pengembangan budaya organisasi dilihat dari kualitas, difokuskan pada kekerapan dan mutu dari unsur budaya organisasi yang dilaksanakan sepenuh hati.

(1) Penumbuhkembangan budaya Semangat. Berdasarkan observasi dan interviu dengan guru dan karyawan didapatkan tentang budaya - budaya yang dikembangkan kepala SMPIT Nur Hidayah antara lain : (a) penumbuhkembangan mutu dari budaya yang dipegang teguh, (b) penumbuhkembangan jumlah nilai semangat, difokuskan pada usaha meningkatnya kuantitas individu yang melakukan tugas dengan semangat tinggi. Usaha penumbuhkembangan semangat dalam melaksanakan pekerjaan juga dilaksanakan dengan membuat daftar kehadiran semua aktivitas, menerapkan penghargaan kepada guru dankaryawan yang mempunyai semangat paling bagus dibanding yang lainnya. Dalam melaksanakan tugas keseharian rajin dan pantang menyerah, berupaya dengan sepenuh tenaga untuk mewujudkan keinginannya. Tugas dan pekerjaan yang menjadi tanggungannya dirampungkan dengan tepat waktu. Menurut rekapitulasi jumlah guru yang tidak hadir selama semester 1 tahun pelajaran 2016/2017 dibawah $2 \%$. Guru dan karyawan yang tidak hadir disebabkan ijin 
atau sakit. Guru rata - rata meninggalkan sekolah sehabis sholat ashar/ pukul 15.30 WIB. Penumbuhkembangan budaya semangat timbul menjadi semangat untuk mensosialisasikan SMPIT Nur Hidayah dalam berbagai aktivitas. Semangat bekerja sebagai manifesti dari fastabiqul khoirot (melakukan perlombaan dalam kebaikan).

(2) Penumbuhkembangan Budaya Kebersamaan. Organisasi adalah sekumpulan individu yang saling membantu bekerjasama dalam rangka menggapai tujuan yang telah ditentukan. Dengan seperti itu kebersamaan merupakan unsur budaya organisasi yang perlu memperoleh perhatian dan dikembangkan oleh ketua organisasi. Lewat bekerja secara gotong royong dalam saling nasihat menasihati dan memperoleh manfaat dari pengalaman yang dipunyai oleh sesama guru dan karyawan, menjadikan suatu norma dan sistem tingkah laku sosial, menyusun pranata sosial, serta keleluasaan berekspresi dan menunjukkan eksistensi diri.

(3) Penumbuhkembangan Budaya Keilmuan. Perubahan pribadi guru dan karyawan adalah awal adanya perubahan yang terjadi di suatu lembaga pendidikan. Pemikiran dan kepercayaan para guru dan karyawan dalam hal perubahan, secara mendasar adalah seperti yang tertulis dalam kitab suci Al Qur'an Surat Ar - Rad ayat 11. Budaya keilmuan dalam ranah pengetahuan dipahami guru dan karyawan sebagai penerapan ajaran islam, seperti yang ditentukan dalam ucapan Nabi Muhammad saw yang berbunyi 'tuntutlah ilmu dari ayunan sampai ke liang lahat'. Usaha menumbuhkembangkan budaya keilmuan yang dilaksanakan pimpinan sekolah lewat koleksi buku yang ditambahkan dan majalah di perpustakaan, mengharuskan guru dan karyawan mendengarkan ceramah keagamaan rutin untuk meningkatkan kapasitas ilmu agama, menganjurkan guru melakukan studi lanjut S1 dan S2, mengikuti kegiatan MGMP Kota Surakarta dan JSIT, mengikuti pelatihan dan pengembangan keprofesian. Tentang masukan untuk melanjutkan ke bangku kuliah, tercatat total 15 orang guru SMPIT Nur Hidayah yang menempuh pendidikan studi lanjut di pasca sarjana.

(4) Penumbuhkembangan Budaya Perilaku Hidup Amar Ma'ruf Nahi Munkar. Perilaku hidup muslim amar ma'ruf nahi munkar menjadi landasan utama organisasi Yayasan Nur Hidayah bagi guru dan karyawan adalah dakwah menyeru kepada kebaikan dan mencegah dari kemunkaran. Tujuan terakhir dari aktivitas yang diketahui dengan amar ma'ruf nahi munkar adalah terciptanya masyarakat yang memiliki akhlak yang mulia. Bagi guru dan karyawan SMPIT Nur Hidayah, akhlak yang mulia sebagai perwujudan dari amar ma'ruf nahi munkar adalah sebagai ukuran kualitas perilaku hidup muslim yang berusaha membuat seimbang antara kehidupan dunia dan akhirat. Panduan bertindak amar ma'ruf nahi munkar adalah atas landasan ajaran islam dalam kitab suci Al - Qur'an Surat Ali Imran ayat 110.

Penumbuhkembangan budaya organisasi yang dilakukan kepala sekolah diantaranya adalah; (1) Guru dan karyawan wajib mengikuti pembinaan rutin pekanan yang diisi langsung dari pembina yang ditunjuk Yayasan Nur Hidayah Surakarta, (2) Guru dan karyawan mengikuti program SSJ (Sedinten Setunggal Juz) dalam membaca al - qur'an sehingga guru tilawah dalam sehari satu juz. Termasuk didalamnya program membaca rutin surat al - kahfi di hari jumat, (3) Guru dan karyawan melaksanakan program tahfiz qur'an sehingga guru dan karyawan memiliki hafalan standar 2 juz, (4) Semua guru dan karyawan adalah Guru PAI ( Pendidikan Agama Islam) sehingga harapannya bisa memberikan keteladanan kepada peserta didik, (5) Guru mengikuti lomba - lomba guru profesional internal SMPIT Nur Hidayah untuk meningkatkan kualitas guru.

\section{Simpulan}

Berdasarkan serangkaian pengamatan, wawacancara dan studi dokumen dapat disarikan sebagai berikut : (1) Peranan kepala sekolah dalam implementasi 
budaya organisasi diarahkan kepada upaya memperluas informasi tentang budaya organisasi, upaya meningkatkan pemahaman agar dapat meyelaraskan perilaku guru dan karyawan sesuai dengan Yayasan Nur Hidayah, serta dijabarkan dalam butir - butir aturan kepegawaian. Sosialisasi budaya organisasi oleh kepala sekolah dengan berbagai cara, antara lain melalui rapat-rapat, situs web sekolah dan pembinaan guru dan karyawan dan lebih khusus pada pembinaan pekanan guru dan karyawan oleh yayasan, (2) Peranan kepala sekolah dalam memelihara budaya organisasi dilakukan melalui berbagai upaya, antara lain : supervisi kepala sekolah, monitoring kegiatan, mengembangkan budaya kebersamaan, menggalakkan pengajian rutin dan evaluasi kegiatan guru dan karyawan, (3) Peranan kepala sekolah dalam mengembangkan budaya organisasi di SMPIT Nur Hidayah diarahkan pada upaya peningkatan keterlibatan, pemberdayaan dan pemeliharaan hubungan interpersonal, sehingga kualitas dan kuantitas pelaksanaan budaya organisasi meliputi budaya semangat, kebersamaan, keilmuan dan budaya perilaku hidup muslim, berupa amar ma'ruf nahi munkar. Upaya yang dilakukan kepala SMPIT Nur Hidayah dalam pengembangan budaya organisasi : (a) mendorong para guru dan karyawan untuk bersemangat fastabiqul khairat, (b) upaya mendorong untuk menjaga kekompakan, kebersamaan sebagai manifestasi kebersamaan Nur Hidayah yang dapat dilihat masyarakat, (c) mendorong para guru untuk meningkatkan kemampuannya melalui studi lanjut, agar meningkat kompetensinya, (d) peningkatan perilaku hidup muslim dengan amar ma'ruf nahi munkar menuju muslim yang beraklaqul karimah.

Berdasarkan teori yang dikemukakan dan hasil penelitian yang sebagaimana yang sudah dikemukakan, dapat disampaikan saran - saran sebagai berikut : (1) Sebaiknya SMPIT Nur Hidayah juga memperhatikan budaya teknologi dalam pembelajaran, pelayanan dan sistem informasi sekolah, (2) Langkah - langkah yang dilakukan kepala SMPIT Nur Hidayah kiranya dapat dijadikan acuan bagi kepala SMP lain, dalam menumbuhkembangkan budaya bagi guru dan karyawan terlebih untuk sekolah swasta islam, (3) Langkah yang dilakukan Yayasan Nur Hidayah kiranya dapat dijadikan acuan bagi yayasan lain dalam mengembangkan budaya organisasi bagi sumber daya manusia.

\section{Daftar Pustaka}

Amir, Y.H. 2011. Kepemimpinan Pendidikan di Sekolah Swasta Berciri Khas Islam. Disertasi, Universitas Pendidikan Indonesia, Bandung.

Arifin, F, dkk. 2014. Organizational Culture, Transformational Leadership, Work Engagement and Teacher's Performance : Test of a Model. International Journal of Education and Research, Vol. 2 No. 1 ISSN: 2201-6333 (Print) ISSN: 2201-6740 (Online) www.ijern. com

Ate, P.M 2014. Budaya Organisasi Sekolah dalam Meningkatkan Kinerja Guru. http://journal. um.ac.id/index.php/jph, Volume 2 Nomor 4 ISSN: 2338-8110

Balkar, B. 2015. Defining an empowering school culture (ESC): Teacher perceptions. Issues in Educational Research, Vol (25) No 3:205

Hoy, W.K \& Miskel, C.G. 2014. Administrasi Pendidikan : Teori, Riset, dan Praktik. Yogyakarta: Pustaka Pelajar

Jurman. 2014. Budaya Organisasi dalam Meningkatkan Kinerja Guru pada SMA Negeri 1 Simuelue Timur. Jurnal Ilmiah Didaktika, Vol. XIV No. 2:275-290

Koentjaraningrat. 2003. Pengantar Antropologi. Jakarta: Rineka Cipta 
Komariyah, C.T. 2006. Visionary Leadership, Menuju sekolah Efektif. Jakarta: Bumi Aksara.

Kotter, J.P dan Hesket, J.L. 1990. Corporate Culture and Performance. New York: The Free Press.

Mala, A.R. 2015. Membangun Budaya Islami di Sekolah. Jurnal Irfani ISSN 1907-0969 E ISSN 2442-8272, Volume 11 Nomor 1: 1- 13

Miles, B.M \& Huberman, A.M. 1992. Analisis Data Kualitatif. Jakarta: UI Press.

Moleong. (2002). Metodologi Penelitian Kualitatif. Bandung: Remaja Rosda Karya.

Mulyasa, E. 2004. Menjadi Kepala Sekolah Profesional. Bandung: Remaja Rosda Karya.

Nasir, M. 2003. Metode Penelitian. Jakarta: Ghalia Indonesia.

Ndraha, T. 2003. Budaya Organisasi. Jakarta: Rineke Cipta.

Patilima, H. 2005. Metode Penelitian Kualitatif. Bandung: Alfabeta.

Profil Satuan Pendidikan/ Lembaga SMPIT Nur Hidayah. http://referensi.data.kemdikbud. go.id/tabs.php?npsn=20328138 diakses tanggal 29 November 2016

Rohidi, T.R. 1994. Pendekatan Sistem Sosial dalam Pendidikan. Semarang: FKIP Press.

Sagala, S. 2013. Memahami Organisasi Pendidikan: Budaya dan Reinventing Organisasi Pendidikan. Bandung : Alfabeta

Schein, E.H. 1995. Organizational Cultures and Leadership. San Fransisco: Jossey Bass

Sergiovani, T.J. 1986. The Principalshi, a Reflective, Practice, Perspective. Boston: Alyyn Bacon Inc.

Siagian, S.P 1995. Teori dan Praktek Kepemimpinan. Jakarta: Bina Aksara.

SMPIT Nur Hidayah Surakarta (20328138) http://sekolah.data.kemdikbud.go.id/index.php/ chome/profil/40BA9D5A-2DF5-E011-B96A-03D2E2FD2161 diakses tanggal 29 November 2016

Suranto. 2005. Budaya Organisasi Sekolah dalam Mencapai Prestasi : Studi Kasus SMP Negeri 1 Sukoharjo Perspektif Naturalistik. Tesis tidak dipublikasikan, UMS, Surakarta

Syafaruddin. 2002. Manajemen Mutu Terpadu dalam Pendidikan. Jakarta: Grasindo

Tahalele. 2006. Bagaimana Memipin Sekolah yang Efektif. Bogor: Ghalia Indonesia

Wahjosumidjo. 2001. Kepemimpinan dan Motivasi. Jakarta: Ghalia Indonesia

Wirawan. 2007. Budaya dan Iklim Organisasi:Teori Aplikasi dan Penelitian. Jakarta:Salemba Empat

Zubaidah, S \& Ayuningtyas, A.E2015. Budaya Organisasi untuk Meningkatkan Profesionalisme Guru di Sekolah. Prosiding Seminar Nasional Pendidikan Ekonomi \& Bisnis Fakultas Keguruan dan Ilmu Pendidikan Universitas Sebelas Maret Surakarta ISBN: 978-6028580-19-9 http://snpe.fkip.uns.ac.id Sabtu, 07 November 2015 